Science-Based Business: Knowledge Capital or Entrepreneurial Ability? Theory and Evidence from a Survey of Biotechnology Start-ups

\author{
Serguey Braguinsky \\ Yuji Honjo \\ Sadao Nagaoka \\ Kenta Nakamura
}

IIR Working Paper WP\#10-05

September 2010

Institute of Innovation Research

Hitotsubashi University

Tokyo, Japan

http://www.iir.hit-u.ac.jp 


\title{
Science-Based Business: Knowledge Capital or Entrepreneurial Ability? Theory and Evidence from a Survey of Biotechnology Start-ups
}

\author{
Serguey Braguinsky, Yuji Honjo, Sadao Nagaoka, and Kenta Nakamura*
}

\begin{abstract}
We present a model of science-based entrepreneurship where ideas initially produced by researchers with high-level knowledge capital may be developed by high-ability entrepreneurs. With moderate investment costs, startups continuously managed by inventors-founders coexist in equilibrium with startups that experience entrepreneurial turnover. The model predicts that startups managed by non-founder entrepreneurs would on average outperform the startups managed by their founders and that better functioning of the market for entrepreneurial talent should result in more entrepreneurial turnover in equilibrium which in its turn leads to more ideas being commercialized and higher rewards to successful startups. The predictions of the model are tested against a unique dataset drawing upon a representative sample of biotechnology startups in Japan and are found to be broadly supported in the data.
\end{abstract}

JLE classification numbers: O31, O32

Keywords: Science-based Business, Biotechnology, Start-ups, Entrepreneurship, Innovation

This version

$2010 / 8 / 30$

\footnotetext{
* Braguinsky (corresponding author), Department of Social and Decision Sciences, Carnegie Mellon University (sbrag@andrew.cmu.edu); Honjo, Faculty of Commerce, Chuo University (yhonjo@tamacc.chuo-u.ac.jp); Nagaoka, Institute of Innovation Research, Hitotsubashi University (nagaoka@iir.hit-u.ac.jp); Nakamura, Graduate School of Economics, Kobe University (knakamura@econ.kobe-u.ac.jp). This paper was written while Braguinsky was visiting Hitotsubashi University Institute of Innovation Research (IIR), during which he participated in the research project on biotechnology innovation collaboratively pursued by the IIR and the Japan Bio Industry Association.
} 


\section{Introduction}

The nature of entrepreneurship in industries that place particularly strong demand on highest-level knowledge and human capital has been examined in several recent contributions (Bhidé [2000], Zingales [2000], Kaplan, Sensoy, and Stromberg [2009], Braguinsky, Klepper, and Ohyama [2010]). Biotechnology industry has attracted particular attention as a primary example of such "science-based" industry (e.g., Zucker et al. [1998]). It has been argued that the role of human capital as a "critical resource" in such industries changes the very essence of how economists define firms and their interaction with markets, and also requires the introduction of radically new management concepts (Zingales [2000], Pisano [2010]). Other studies, however, have found that more "traditional" theories of the firm actually mesh surprisingly well with evidence from such high-tech, science-based industries (Kaplan et al. [2009]).

In this paper, we present a simple theory of science-based entrepreneurship, to deepen our understanding of the factors of entrepreneurial success in industries such as the biotechnology industry. We then empirically probe some of the predictions of the theory by using a hand-collected data set on biotechnology start-ups in Japan.

In our theory, the input from basic research is a "critical resource" in the sense that an innovative startup is not possible without it. There is another critical resource, however, which we call "entrepreneurial ability" but which could be interpreted broadly as including knowledge of the market and experience of doing business in a given industry. 
This resource has repeatedly been found to be the most important predictor of success in high-tech industries of the past (e.g., Klepper [2002]) and we conjecture that in this sense, science-based business is no different. The expected value of a startup is thus a product of two factors, the input from the basic research and the input in the form of entrepreneurial ability.

In the model, startup founders are endowed with seeds coming from basic research, the commercial values of which are not known. Founders are heterogeneous in entrepreneurial ability and those of them with low ability may hire those with high ability to develop their seeds. A founder either retains the seed for the future at no investment cost, or he invests to learn the value of the seed. In the latter case, if the seed turns out to be no good, a high-ability founder becomes a "seedless" entrepreneur who may move to another startup to develop a good seed.

The implications of the model shed light on several characteristics of science-based business that featured prominently in past studies. First, the model highlights the crucial role played by the "market for ideas" (see Gans, Hsu, and Stern [2002]). Without such a market, which we model as the market where talented entrepreneurs are matched with commercially promising seeds, the cost of investing to learn the quality of the seed can easily become prohibitive even for seed owners with the highest entrepreneurial ability, leading to an equilibrium characterized by sluggish growth and "dormant seeds" that never get a chance to be evaluated. Second, the model implies 
that lowering investment costs results in fuller transfer of seeds from basic researchers to high-ability entrepreneurs as they reach the potential commercialization stage, which in turn leads to an equilibrium with fast selection of seeds to be either developed or discarded, and higher expected payoffs, in line with the model in Aghion, Dewatripoint and Stein [2008]. Third, in equilibrium with moderately high investment costs, there will be startups continuously managed by original inventors alongside startups that experience a change in management. Furthermore, the model predicts that high levels of investment and better development of seeds will be primarily associated with the startups that experience a change in management.

We probe the predictions of the model using a unique hand-collected dataset on the Japanese biotechnology industry. While the United States remains the undisputed leader in this area, since the late 1990s Japan has adopted a wide range of regulatory, financial and other measures to spur the growth of the domestic biotechnology industry (Honjo et al. [2009]). Partly as a result of that, the number of biotech firms in Japan had increased from 116 to 586 from 1994-2006 (Motohashi [2007], p. 2), making the Japanese biotechnology industry the second largest in the world after the U.S. in terms of sheer number of firms. Japan continues to lag behind the U.S., however, in the number of IPOs (around 20 IPOs as of 2006 compared to 330 in the U.S.) and the volume of sales (barely over 10 percent of the U.S. level; see Motohashi [2007]).

Our theory implies that in order to catch up with the U.S. not just in quantity but 
also in the quality of startups, Japan needs to create conditions under which more seeds are transferred to specialized entrepreneurs. In line with the theory, we find high-investing and faster-growing startups, as well as startups that successfully conducted IPOs tend to be those that had experienced entrepreneurial turnover at some point after they were founded.

Our paper has important management and policy implications. To the best of our knowledge this is one of the first studies to demonstrate, both theoretically and empirically using a relatively large and representative sample of startups the importance of having specialized entrepreneurs develop and commercialize seeds produced from basic research. High-level specific human capital may be important at the inception but it is relegated to a supporting role when it comes to developing a commercially viable product. Startups in countries where the market for entrepreneurial talent is not yet as developed as it is in the U.S. (such as Japan), may also benefit from international cooperation. In terms of policy, our findings suggest that the Japanese government should try not so much to emulate the early development stage of the U.S. biotechnology industry by supporting university-based businesses operating in local business communities, but instead should concentrate its resources on developing nation-wide market for entrepreneurial talent.

The rest of the paper is organized as follows. In the next section we briefly discuss past research. No attempt is made to survey the fast-growing literature on the biotechnology industry as a whole; instead, we focus on studies, where we think our paper can contribute some new theoretical insights or interpretations of empirical evidence. 
Section 3 presents our model and discusses its implications for markets and startups. In Section 4 we describe the data and test several predictions of the model using these. Section 5 concludes and contains further discussion of our findings.

\section{Connection to past research}

Zucker et al. [1998] examined the process of entry and development of the American biotechnology industry and concluded that "the growth and location of intellectual human capital was the principal determinant of the growth and location of the industry itself," with the industry itself being "a testament to the value of basic research." (p. 302) The fundamental feature of the biotechnology industry as a science-based business and the dramatic impact its emergence has had on commercial activities by universities, such as patenting, licensing and investing in spinouts has been confirmed by numerous subsequent studies (see, for example, Jensen and Thursby [2001], Thursby and Thursby [2002], Zucker and Darby [2006]).

Even though there is thus little doubt that specific high-level human capital is of crucial importance for a potential biotechnology innovation, it is less certain that the same specific human capital remains critical during the process of developing and implementing

an innovation. In a careful study, Gittelman and Kogut [2003] find that important scientific papers written by academic researchers and high-impact innovations are actually negatively correlated. They conclude that science-based business in general and the biotechnology industry in particular need separate organizational entities (small 
research-intensive firms) whose task would be to combine valuable knowledge and to select scientific ideas to produce important technical innovations. Similarly, Gans et al. [2002] find that in the biotechnology industry, start-up innovators earn returns not by pursuing their businesses independently but by acting as upstream "suppliers" of technology, with an important role played by third-party "brokers."

This theme has been pursued further in the bulging literature on strategic alliances in the biotechnology industry (see, e.g., Lerner and Merges [1998], Baum, Calabrese and Silverman [2000], Rothaermel and Deeds [2004], etc.). In particular, it has been found that forming alliances at an early stage (including the exploratory stage) helps especially smaller startups (Rothaermel and Deeds [2004]). Shan, Walher and Kogut [1994] and Baum, Calabrese and Silverman [2000] hypothesized that the relationship between alliances and better performance of start-ups can be reciprocal but they only found evidence that alliances affect performance positively but not vice versa.

The nature of entrepreneurship in science-based business and the biotechnology industry in particular has been conceptualized in broadly two different ways. According to one approach, "the innovations which underlie biotechnology are properly analyzed in terms of naturally excludable knowledge held by a small initial group of discoverers, their coworkers, and others who learned the knowledge from working at the bench-science level with those possessing the requisite know-how." (Zucker et al. [1998], p. 291). Zingales [2000] and Rajan and Zingales [2001] argue that because of these features, the traditional 
theory of the firm, which associates this concept with strictly hierarchical control over a well-defined tangible critical resource may not be applicable to the biotechnology industry. Having high-level specific human capital as the "critical resource" may lead to "deintegrating the firm", potentially paralyzing its ability to function effectively. In a similar vein, Pisano [2010] concludes that new organizational forms, beyond the traditional concept of a firm and even beyond the concept of traditional venture capital are required to meet the challenges of science based-business.

Kaplan, Sensoy and Stromberg [2009] put these ideas to test using a dataset of venture capital-backed startups in biotechnology and other high-tech industries. They find that, contrary to the perception of human capital being all-important, in virtually every firm, there was little change in their core line of business from age 2 onward whereas there was considerable turnover in the human capital, contradicting the perception that biotechnology firms are crucially dependent on specific human capital. Notably, all their firms experience "dramatic growth in revenue, assets and market value (although they do not become profitable)." (Kaplan et al. [2009], p. 77) Hence, while their conclusion that the traditional theory of the firm is still quite relevant even in science-based business is persuasive with regard to the select sample of successful startups, it does not necessarily contradict the conclusions in Zingales [2000] which, almost by construction, apply to somewhat dysfunctional firms.

A theory proposed by Aghion, Dewatripoint and Stein [2008] hints at one 
possible way of reconciling the two approaches. In their model, the initial basic research stage of developing a potential high-impact innovation is carried out in academia and may be characterized by the lack of focus and self-indulging behavior of scientists, but once the idea approaches the commercialization stage, the control over its implementation should be given to the private sector and carried out with much greater focus.

One crucial thing not modeled in Aghion et al. [2008] is how this turnover happens and who selects ideas for innovations. A different kind of a critical resource is all-important at this stage, and this resource is the high-ability entrepreneurs ("brokers" in the "market for ideas" as in Gans et al. [2002]). Such entrepreneurs would normally also possess high-level knowledge in biotechnology but they are not necessarily star scientists while their biggest asset is the knowledge of the market that comes from experience in the industry or in venture capital. In the next section we construct a simple model that captures the essence of this story and derive some implications about the nature of innovation in the biotechnology industry that will then be tested against the data.

\section{The model}

We exploit two features inherent in the nature of science-based business. First, startups are based on a seed developed through scientific research and startup founders must possess a high-level specialized knowledge in science. Second, failure rates are high because many seeds that look promising initially turn out to be commercially not viable. Thus, even startups established by founders with high entrepreneurial ability often find 
themselves lacking a good project (seed) after failing to develop their original idea into a commercial product. The key assumption (which finds support in evidence, including the evidence from Japan presented below) is that such a "seedless" entrepreneur can under certain circumstances put his talent to work with a seed invented by someone else. This "recycling" of entrepreneurial talent requires a functioning "market for ideas" (or market for entrepreneurial talent, as the case might be) but it has the potential to dramatically change the nature of the game in science-based business.

The crucial role is played by investment costs involved in evaluating and pursuing the development of a seed. If such investment costs are high (which may be the result of poor protection of property rights in the market for ideas - see Gans et al. [2002], or of poor development of capital markets), few or even no seeds will be transferred to high-ability entrepreneurs in equilibrium, resulting in sluggish development and low values of startups. In contrast, in markets with low investment costs, all seeds get evaluated fast and good seeds are developed by high-ability entrepreneurs leading to high values of startups. We develop a stylized model that formalizes these ideas. Longer proofs are in the appendix.

\subsection{The set-up}

We generalize and adapt the model in Jovanovic and Braguinsky [2004]. At the outset startups differ in the entrepreneurial ability, $x$, of their founders. Each startup is endowed with a seed, and the quality of the seeds, $z$, differs over startups. Some startup founders 
with high entrepreneurial ability may find themselves with useless seeds and vice versa. The market for entrepreneurs then serves to re-deploy high-ability entrepreneurs from useless seeds to good seeds. A startup's value is $x z$. Thus the quality of the seed, $z$, and the entrepreneur's ability to develop it, $x$, are complements.

Among startups, $x \geq 0$ is distributed according to the cumulative distribution function $F(x)$. Seeds are either good or useless: $z \in\{0,1\}$. A fraction $\lambda$ of seeds is good, and the fraction $1-\lambda$ is useless; also, we assume for simplicity that $\lambda$ does not depend on $x$, so all startups are equally likely to have a good seed.

We assume that entrepreneurial ability $x$ is known. Evaluating and developing a seed is a full-time activity, so that an entrepreneur can handle only one seed at a time. A startup founder has two options: (i) retain the seed for possible future development at no cost (hereafter "no-investment option"), or (ii) invest $C>0$ to learn and certify the quality of the seed (hereafter "investment option"). All startups are risk-neutral and maximize the discounted expected value, with the reservation value of exit normalized to zero.

Startups cannot change seeds. ${ }^{1}$ They can, however, hire entrepreneurs to develop certified good seeds. If a startup founder hires an entrepreneur with ability $x$, the startup uses its own seed, $z$, and the entrepreneurial ability of the entrepreneur it has hired, $x$ '. The value of such a startup will thus be $x^{\prime} z$. To the seed owner who hires an entrepreneur,

1 This assumption is made to concentrate on turnover of managerial talent, which is our focus here, but it is not essential for the properties of the equilibrium below. This is discussed further in the concluding section. 
then, only the ability of the hired entrepreneur matters, while for the hired entrepreneur all potential employers with good seeds have the same value $(z=1)$. A competitive market then ensures that entrepreneurs receive compensation commensurate with their marginal contribution (ability $x$ ) while seed owners who hire them receive the same compensation $q$.

Events occur in four stages:

1. A continuum of startups forms.

2. Startups choose whether to incur the investment $\operatorname{cost} C$ to learn the quality of the seed or to hold on to the seed of unknown quality under the "no-investment option". The startups that paid $C$ observe the quality of the seed $z$. Those with $z=1$ choose whether to develop the seed on their own or hire a "seedless" entrepreneur to develop the seed. Those with $z=0$ become "seedless" entrepreneurs that may be hired to develop seeds owned by startups with $z=1$.

3. The market for entrepreneurs clears with owners of good seeds who hire others to develop their seeds receiving $q$ and seedless entrepreneurs with ability $x$ receiving $x$ $-q$. This market is Walrasian in that startups take prices as given and there are no out-of-equilibrium transactions.

4. Startups with certified good seeds $(z=1)$ proceed to the development stage.

\subsection{Expected values}

If a startup chooses the no-investment option (i) it retains the ownership of the seed and will privately observe its quality at some future date, at which point it will decide whether 
to pursue the seed's development or exit the industry. We assume that without incurring investment cost $C$ a startup cannot certify the quality of its seed, so it will not be able to hire another manager. Hence, the expected value of such a startup is given by

$$
E_{N I}=\beta \lambda x
$$

where $\beta$ is the discount factor.

If a startup chooses the investment option (ii), there are two possible cases. In the first case a founder invests $C$ to learn and certify the quality of the seed in anticipation that he will hire a seedless entrepreneur to develop the seed if $z=1$. It is shown later that such founders are never hired to develop other startups' seeds in equilibrium so that they receive compensation $q$ if and only if $z=1$. Thus the expected private value of the startup for a founder in this case is

$$
E_{I 1}=\lambda q-C
$$

Now consider a founder who chooses the investment option with a view to developing a good seed on his own, while also expecting to be hired to develop a good seed owned by someone else if his own seed turns out to be useless. Again, we show later that these expectations are fulfilled in equilibrium. Hence, such entrepreneurs' expected private values are given by

$$
E_{I 2}=\lambda x-C+(1-\lambda)(x-q)=x-C-(1-\lambda) q .
$$

\subsection{The no-investment equilibrium}

Let the support of $x$ be given by $\left[0, x_{\max }\right]$, where $x_{\max }$ is finite. We have: 
Proposition 1. If the investment costs are very high, specifically, if

$$
C \geq \lambda(1-\beta \lambda) x_{\max },
$$

no startup chooses the investment option and no entrepreneurs develop others' seeds. In this case, $R \& D$ investment levels and startup value are low, and seeds are evaluated and developed slowly, with relatively low payoffs even for good seeds.

Proof: The expected value of a startup founder who chooses the investment option and expects to hire an entrepreneur to develop the seed in case $z=1$ has to be non-negative in (2), implying that $q \geq C / \lambda$. The expected value of a startup founder who chooses the investment option and expects to be hired to develop a good seed in case $z=0$ is given by (3). It is easy to see that under condition (4) it will be less than $E_{N I}$ in (1) for the entrepreneur with the highest $x$ even if the transfer price $q=C / \lambda$. Hence, no inventor chooses the investment option, rendering the transfer of seeds to more capable entrepreneurs impossible. The remaining claims follow immediately.

\subsection{Equilibrium with the investment option and entrepreneurial turnover}

Assume now that investment costs are not prohibitively high, so that

$$
C<\lambda(1-\beta \lambda) x_{\max },
$$

Then there exists an equilibrium in which some or possibly all startups exercise the investment option, and seedless entrepreneurs with high $x$ are hired to manage good seeds by startup founders with low $x$. We illustrate one such equilibrium (in which some but not all startups exercise the investment option) in Figure 1, and describe it below. 
[Figure 1 around here]

The key feature of the equilibrium are two real numbers, $\hat{x}$ and $\tilde{x}$. These numbers divide the set of $x$-values into at most three regions - top, middle and bottom. Startups that invest $C$ to learn and certify $z$ and hire seedless entrepreneurs to develop their seeds if $z=1$ come from the bottom region, while startups that invest $C$ and either develop their seeds if $z=1$ or are hired to develop good seeds for the startups from the bottom region if $z=0$ come from the top region. Startups from the middle region (which might be empty as shown below) choose the no-investment option and hold on to their seeds. We start describing the equilibrium with an account of Stage-2 actions and Stage-3 private values of startups in each region.

The Bottom Region: $x \leq \tilde{x}$, where $\tilde{x}$ is the lower bound of the middle region in case the latter is non-empty, $x \leq \hat{x}$, where $\hat{x}$ is the lower bound of the top region otherwise --Startup founders in this region pay $C$ and certify the quality of the seed $z$. If $z=1$, they hire an entrepreneur from the top region and all receive the same transfer price $q$. If $\hat{x}>\tilde{x}$, founder $\tilde{x}$ is indifferent between receiving $q$ with probability $\lambda$, on the one hand, and choosing the no-investment option with the expected value $\beta \lambda \tilde{x}$, on the other hand:

$$
\beta \lambda \tilde{x}=\lambda q-C .
$$

If $\hat{x} \leq \tilde{x}$ so that the middle range in empty, the founder $\hat{x}$ is indifferent between receiving $q$ with probability $\lambda$, on the one hand, and developing his own seed in case $z=1$ or being hired to develop someone else's seed in case $z=0$, on the other hand: 


$$
\begin{aligned}
& \lambda q-C=\hat{x}-C-(1-\lambda) q, \\
& \text { or } \quad \hat{x}=q .
\end{aligned}
$$

The Middle Region: $x \in(\tilde{x}, \hat{x})$ if $\hat{x}>\tilde{x}$, empty otherwise --- Startup founders in this region choose the no-investment option. Intuitively, startups in this region have too good management to be willing to pay for development by another entrepreneur, but are not good enough to choose the investment option.

The Top Region: $x \geq \hat{x} \quad$--- Startup founders in this region pay $C$ and learn the quality of the seed $z$. If $z=1$, they proceed to develop it. If $z=0$, they become seedless entrepreneurs and sell their services to startups in the first region. If $\hat{x}>\tilde{x}$, founder $\hat{x}$ is indifferent between the expected value of this option given by (3) and the expected value of the no-investment option (1):

$$
\beta \lambda \hat{x}=\hat{x}-C-(1-\lambda) q
$$

If on the other hand, $\hat{x} \leq \tilde{x}$ so that the middle range in empty, $\hat{x}$ is indifferent between developing someone else's good seed and exiting, that is, we once again have

$$
\hat{x}=q .
$$

Demand $=$ Supply. --- Demand for entrepreneurs must equal their supply:

$$
F(\min [\tilde{x}, \hat{x}])=(1-\lambda)(1-F(\hat{x}))
$$

Proposition 2. If condition (5) holds, the investment option and entrepreneurial turnover occur in equilibrium. Furthermore,

- Either $\hat{x}>\tilde{x}$ where 


$$
\hat{x}=\frac{(1-\lambda) \beta}{1-\beta \lambda} \tilde{x}+\frac{C}{\lambda(1-\beta \lambda)}
$$

and $q<C / \lambda(1-\beta)$ solves

$$
\lambda F\left(\frac{\lambda q-C}{\beta \lambda}\right)=(1-\lambda)\left[1-F\left(\frac{C+(1-\lambda) q}{1-\beta \lambda}\right)\right],
$$

- $\operatorname{Or} \hat{x} \leq \tilde{x}$ and $q \geq C / \lambda(1-\beta)$ solves

$$
\lambda F(q)=(1-\lambda)[1-F(q)] .
$$

In the latter case the no-investment option does not occur in equilibrium.

Proof: see appendix.

Figure 2 present a numerical example of the equilibrium of the first type (with non-emtpy middle region, hence, with no-investment option as part of equilibrium behavior). Figure 3 present a numerical example of the equilibrium of the second type, where the no-investment option is dominated by the investment option and subsequent hiring of seedless entrepreneurs from the top region by founders in the bottom region.

[Figures 2 and 3 around here]

Comparative Statics - The comparative statics of the model are given by the following

Proposition 3. Other things equal, more seeds will be certified and transferred to high-ability entrepreneurs in equilibrium if investment costs $C$ and the discount factor $\beta$ are low, but the effect of the increase in the fraction of good seeds $\lambda$ is ambiguous.

Proof: see appendix. 
Investment costs $C$ are likely to be lower if property rights for ideas are well defined, and if there is an abundant supply of venture capital (e.g., Gans et al. [2002]). Our model suggests a caveat, however. One interpretation of the discount factor $\beta$ is that "slow" approach taken by a startup can result in losing the seed because patent rights of the inventor may expire or be successfully challenged in court (such cases were indeed confirmed in our interviews with Japanese university startups as documented below). Hence, to increase the transfer of good seeds to high-ability entrepreneurs, property rights to ideas should be strong but at the same time short-lived, rendering unprofitable the option of holding on to the seed by founders of low entrepreneurial ability.

Even though the effect of a higher fraction of good seeds $\lambda$ is theoretically ambiguous, numerical simulations show that for reasonable parameter values it also leads to more good seeds being transferred in equilibrium (details are available upon request). Increased supply of better-quality (that is, more commercializable) seeds can be expected to come from increased willingness of universities and basic research institutions in general to license their innovations and place more emphasis on the ties between university and industry research, the pattern that has also been well-documented in studies on recent trends in university entrepreneurship (e.g., Thursby and Thursby [2002]; Shane [2002]).

\subsection{Testable predictions}

We concentrate on the equilibrium that includes but is not limited to the no-investment option and summarize empirical predictions that are then tested against the data. 
Note first that improving the conditions for entrepreneurial talent to be "recycled" should result in more startups, especially by scientists and those formerly employed in academia with potentially commercializable seeds from basic research. This prediction, of course, is not surprising and is not particularly specific to our model. A more discriminating prediction is that as the number of startups founded around basic research ideas increase, more of those startups will use specialized entrepreneurial talent coming from non-academia to develop their ideas. Hence, the model predicts that the increase in the number of startups founded by academic researchers will tend to happen together with the decrease in the number of startups still managed by academic researchers after experiencing management turnover. We thus have:

EP1. Better functioning of the market for entrepreneurial talent and lower investment costs (such as the introduction of the equivalent of the Bayh-Dole act) should result in more startups created with core technology coming from basic research and founded by former scientists and academia employees. At the same time, startups experiencing changes in management will tend to be managed less by academic researchers and more by entrepreneurs with prior experience in the industry.

We now turn to the predictions of the model regarding startups that experience entrepreneurial turnover versus those that don't. The model predicts that startups that do not change management will be comprised of two subgroups. The first such subgroup will consist of startups managed by founders with entrepreneurial ability in the middle 
range, choosing the no-investment option and neither learning the quality nor developing their seeds. The other subgroup will be startups managed by high-ability founder-entrepreneurs that exercised the investment option and learned that $z=1$. If the fraction of good seeds $\lambda$ is low (as available evidence leads us to expect might be the case - see e.g., Pisano [2010]), we can expect the sample of surviving startups in the data that do not undergo entrepreneurial turnover to be pretty much dominated by the former subgroup.

In contrast, surviving startups that do change managers in charge will be comprised only of those that have a certified good seed. Hence, a testable prediction of the model is that an average startup that subsequently experiences entrepreneurial turnover will be more likely to have a certified good seed to be developed at the outset than an average startup that does not experience entrepreneurial turnover. It is natural to expect that a startup with a proven commercially viable seed will be able to raise a larger amount of start-up capital and will have a larger initial size. Thus, we have

EP2. Entrepreneurial turnover should be associated with larger initial capital and larger initial size of the startup.

Also, all startups that experience entrepreneurial turnover will be managed by entrepreneurs in the top part of the ability distribution and will have their seeds being developed, while only a (relatively small) fraction of those that do not experience such turnover will be so. Hence, an average startup that does experience entrepreneurial turnover will be more likely than its counterpart that does not experience such turnover to 
pursue an active R\&D program and to generate higher shareholders' value. The latter will be reflected in higher amounts of raised capital and larger firm size. Higher shareholders' value will also tend to be manifested in IPO events. Thus,

EP3. Entrepreneurial turnover should be associated with higher R\&D investment, larger amounts of raised capital, larger size of the firm, and higher probabilities of IPO.

In the model, the startups with $z=1$ founded by entrepreneurs in the low part of the ability distribution immediately hire high-ability entrepreneurs to develop the seed. In reality the process of finding a suitable entrepreneur can take some time. If the startup is only able to start moving with developing its seed after a high-ability entrepreneur has been hired, the time that elapses between entry and the time the startup hires a new high-ability entrepreneur to develop its seed will not affect the flow of R\&D investment, but it will affect the amount of capital raised and the startup's size because these increase only gradually as the startup moves through the seed development stage. Hence, we have one more, rather discriminating prediction of our model:

EP4. The positive effect of entrepreneurial turnover on the amount of raised capital and startup size will be an increasing function of the new entrepreneur's tenure after controlling for the startup age. The positive effect on $R \& D$ expenditure, however, will be independent of the new entrepreneur's tenure. 


\section{Testing the model: entry and growth in the Japanese biotechnology industry}

\subsection{The data}

The data come from two surveys of firms in the Japanese biotechnology industry conducted by Japan Bioindustry Association (JBA) with the support of the Hitotsubashi University Institution of Innovation Research (IIR) for the questionnaire designs in 2008 and 2009. JBA is a non-profit organization dedicated to the promotion of the Japanese biotechnology industry. In order to obtain information on new ventures in the biotechnology industry, the so-called "bio-ventures," JBA has been constructing the list of firms and conducting a simple yearly questionnaire survey since 2002 .

The extended questionnaires designed jointly by JBA and IIR was sent out to 770 firms and 716 firms in 2008 and 2009 surveys, respectively. In order to be included into surveys, firms had to satisfy two criteria: (1) they had to be operating in the biotechnology industry as classified by the Japanese Industrial Standard (JIS) classification, and (2) they had to be small or medium enterprises under the Small and Medium Enterprise Basic Law of Japan (300 or fewer regular employees or capital stock of no more than 300 million yen - about $\$ 3$ million). Firms that did not meet either of these criteria were excluded from the surveys. The numbers of effective responses was 309 in both years, with response rates of 40 and 43 percent for 2008 and 2009, respectively. We further excluded from analyses some special types of firms, such as firms conducting solely export-import operations and non-profit organizations established solely for $R \& D$ purposes. As a result, 
the final sample is composed of 292 firms (2008 survey) and 281 firms (2009 survey).

The respondents were asked to provide information about the year the firm was founded as well as the year in which it entered the biotechnology industry. Only about 7 percent of the firms reported that they had been founded prior to entry into the biotechnology industry, so that 93 percent of the sample consists of de novo startups. A lion's share of firms (88 percent) were founded after 1990, and more than 70 percent of the sample were founded in 2000 or later, presumably because several policies for the promotion of new ventures, such as tax reform for business angels and the setup of the technological license office (TLO), accompanied by the introduction of its equivalent of the Bayh-Dole Act were introduced in Japan in the late 1990s.

The questionnaires also asked whether the startup was managed by its founder at the time of the survey or if there had been a change of the CEO. In the latter case, the respondents were also asked to report how many years the current CEO had been in charge. Other questions requested information about the seed technology at the time of the startup and the current seed technology (if different from the startup technology), R\&D expenditure, the amount of capital and the number of employees at the time the firm was founded and at the date of the survey, whether the firm had received venture capital funding, whether it had patents granted or applied for in Japan and in the United States and whether it had successfully conducted or planned to conduct IPO in the near future (this latter question was asked in the 2008 survey only). The variables derived from these responses 
are used to test the model below.

The data also contain information about the area of the main activity of the startup. Slightly less than two thirds of the startups in the sample reported that their main area of R\&D activity was the development of new medical products (including developing new drugs), the rest were conducting most activity in bioengineering, environment and new energy resources and so on. Detailed information about the current CEO's background (such as education, age, and prior work experience) was also provided, and we use these as controls where appropriate.

Arguably the biggest advantage of our data is that the sample is not limited to successful startups (such as VC-backed startups or startups that had already conducted IPO). Just slightly over 27 percent of the startups in our sample report having received financing from venture capital and less than 10 percent had conducted IPO or at least had specific plans to conduct IPO at the time of the surveys. In contrast, almost half of the respondents reported having applied for or being granted patents in the United States and 70 percent had patents applied for or granted in Japan. There is also large variation in market capitalization, R\&D expenditure and the number of employees. The data thus present us with a unique opportunity to test the predictions of our theory on a relatively large and reasonably representative sample of biotechnology startups. Table 1 presents the basic summary statistics for the sample. 


\subsection{Entry cohorts and types of entrepreneurs}

We examine how empirical predictions of our theory in Section 3 hold against the data. In Table 2 we present evidence on the evolution of types of startups by four entry cohorts: prior to 1990, 1990-1999, 2000-2004, and 2005-2009. As Japan introduced measures aimed at improving conditions for science-based startups, EP1 predicts that the number of such startups should increase but those firms that experience management turnover should be managed more by entrepreneurs with non-academic background.

The data in Table 2 provide strong support for these predictions. The sample of all startups is divided into those managed by their founders at the time of the survey and those managed by non-founder entrepreneurs at the time they were surveyed. The data show that both categories equally experienced a strong increase in the fraction of startups whose core technologies draw on basic research (developed at universities or public research corporations). Paralleling this, among the startups managed by their founders the fractions of those founded by former scientists and individuals formerly employed in academia increased dramatically (from less than 27 percent to more than 57 percent in the former category, and from 6 percent to 37 percent in the latter category).

But among the startups already managed by non-founders, the fractions of those whose entrepreneurs are former scientists and academic employees actually fell sharply throughout the 1990 s and the 2000s. Hence, while policy measures aimed at promoting startups based on academic research have resulted in a dramatic increase in the number of 
new startups in the biotechnology industry founded by scientists and individuals formerly employed in academia, they seem to have also resulted in more frequent replacement of former scientists and academics by specialized entrepreneurs in the startups experiencing managerial turnover.

\subsection{Turnover of entrepreneurs and startup size at the time of founding}

We now turn to testing the predictions of the theory related to the effects of entrepreneurial turnover. We predict that startups experiencing entrepreneurial turnover should have proven good seeds at inception, which will be manifested in higher initial amounts of raised capital and larger initial size (EP2). To test this prediction we estimate the following regression:

$$
\log _{-} F S_{0 i}=\alpha+\beta_{1} E T_{i}+\gamma X_{i}+\varepsilon_{i}
$$

where $\log _{-} F S_{0_{i}}$ is the natural $\log$ of startup $i$ 's size in the year it was founded, measured by either paid capital or the number of employees in actual estimations below, $E T_{i}$ is the dummy equal to 1 if the startup was managed by a non-founder CEO at survey date and zero otherwise, and $X_{i}$ is a vector of controls. Since the amount of initial capital (and possibly also the initial number of employees) will be strongly affected by the timing of entry, we include 48 founding year dummies in the vector of controls $X_{i}$ and also seven dummies corresponding to different areas of activity of the startup.

The baseline specification contains only the above controls, and the results are presented in the first and third columns of Table 3 (with log initial paid capital and log 
initial number of employees as the dependent variables, respectively). The main prediction of our theory is that the coefficient $\beta_{1}$ should be positive and significant (EP2), and this prediction is very strongly supported. The estimates indicate that startups that experience subsequent entrepreneurial turnover have initial paid capital more than twice as large as startups that don't experience such a turnover $(\exp (0.719)-1)$, and have 46 percent more employees $(\exp (0.381)-1)$. As expected, entry year dummies are jointly very highly significant $(F$-statistic $=51.66$ with $\log$ initial capital as the dependent variable and $F$-statistic $=18.17$ with log initial number of employees as the dependent variable) but areas in which startups conduct their primary activity are jointly not significant at conventional levels in either regression.

We then add more controls for firm, technology and the current CEO background, and what may be thought of as the intrinsic quality of the seed. To control for firm background we use the dummy equal to one if the startup was founded before it entered the biotechnology industry (hence, was a diversifying entrant) and zero otherwise, the dummy equal to 1 if the core seed technology at the time of entry into biotechnology came from basic research and zero otherwise. To control for CEO background, we include two dummies, one equal to 1 if his previous job was in scientific research and 0 otherwise, and the other equal to 1 if CEO's previous job was that of a top manager and 0 otherwise (the basis for comparison are CEOs whose pre-startup jobs were in other commercial activities, such as sales, marketing, accounting and so on). We further distinguish between CEOs 
who were previously employed in academia and in large corporations (with the basis for comparison being small and medium-size firms and financial institutions) and we also include in the vector $X_{i}$ age, minus tenure in the startup as a proxy for prior labor market experience and the dummies capturing the CEO's educational attainment (one dummy equal to 1 if the founder has a Ph.D. in science and engineering and 0 otherwise, and the other equal to 1 if the founder has B.A. or M.S in science and engineering and 0 otherwise). Finally, to control for the intrinsic quality of the seed we also include the dummy equal to 1 if the startup has applied for or was granted a patent in the U.S. and 0 otherwise.

The results of estimating regression (13) in these specifications with log of initial paid capital and the log of the initial number of employees as the dependent variables are presented in the second and fourth columns of Table 3, respectively. Including all these extra controls has little effect on $\beta_{1}$ : entrepreneurial turnover is still estimated to be associated with 88 percent increase in initial capital and with 50 percent more employees at the time of founding, still statistically significant at 1 percent level. Among the controls, core technology coming from basic research (that is, developed in a university or a public research corporation) has a negative effect on initial capital, while patenting activity in the US, as expected, has a strong positive impact on both initial paid and initial number of employees. The variables capturing CEO's background and education, on the other hand, are jointly not statistically significant and the areas in which startups conduct their primary activity also remain jointly not significant. 


\subsection{Turnover of entrepreneurs and $R \& D$ expenditure}

The prediction of the model is that entrepreneurial turnover should be associated with higher R\&D expenditure (EP3) and that, moreover, this effect should be independent of the number of years the new entrepreneur had been in charge (EP4). To test this prediction we estimate the following regression:

$$
\log _{-} R D_{i}=\alpha+\beta_{1} E T_{i}+\beta_{2} \text { tenure }_{i}+\beta_{3} E T_{-} \text {tenure }_{i}+\gamma X_{i}+\varepsilon_{i}
$$

where $\log _{-} R D_{i}$ is the natural $\log$ of $\mathrm{R} \& \mathrm{D}$ expenditure by startup $i$ in the year of survey, $E T_{i}$ is, once again, the dummy equal to 1 if the startup was managed by a non-founder CEO at the date of a survey and 0 otherwise, tenure $_{i}$ is the CEO's tenure on the job, and ET_tenure ${ }_{i}$ is the interaction term between non-founder CEO and tenure. The main prediction of the theory is that the sign of $\beta_{1}$ should be positive, while the coefficient $\beta_{3}$ should be close to zero and should not change the impact of $\beta_{1}$.

The results are presented in Table 4. In the first two columns we limit the vector of controls to seven dummies corresponding to different R\&D activity areas and to firm age and its square term. The coefficient on the dummy capturing entrepreneurial turnover is large and statistically significant, although only on 10 percent level, while the coefficients on CEO tenure and its interaction term with entrepreneurial turnover are statistically indistinguishable from zero, as predicted by theory. When these two variables are excluded (in the second column), the magnitude of the coefficient on the non-founder CEO dummy barely changes, but standard errors go way down, making it statistically 
significant at 1 percent level. The fit of the regression also improves, so we concentrate on the specification that excludes these variables from now on.

The magnitude of the coefficient $\beta_{1}$ estimated in the second column of Table 4 indicates that entrepreneurial turnover is associated with 112 percent $(\exp (0.750)-1)$ increase in R\&D expenditure by an average startup. ${ }^{2}$ Not surprisingly, the areas of activity in which startups conduct their R\&D (coefficients not shown) are now jointly highly significant $(F$-statistic $=16.56)$ and so are firm age and its square term.

Estimations presented in the third column of Table 4 add more controls. Specifically, vector $X_{i}$ now includes also our proxy for the quality of the seed (the dummy reflecting patenting activity in the US) and all the dummies (not shown) reflecting firm and CEO backgrounds, education and experience as in the previous subsection. None of these extra controls are either separately or jointly significant at conventional levels (areas of activity dummy remain jointly statistically significant at 1 percent level), and including them affects the coefficient on the non-founder CEO dummy only marginally. It is only when we also add the control for the startup size (which itself is strongly positively associated with entrepreneurial turnover in our theory and in estimations presented in the next subsection) in the fourth column that the coefficient on the non-founder CEO dummy is reduced in magnitude by about $1 / 3$ and becomes slightly less statistically significant.

2 The difference looks even more striking in raw data: startups that experienced entrepreneurial change spend on average 4.25 times more on $R \& D$ than startups that did not $(3,815$ million yen in the former category versus 897 million yen in the latter category). 


\subsection{Turnover of entrepreneurs, firm size, and IPO process}

The model predicts that the amount of capital raised by the firm and its size (measured by the number of employees) should be positively associated with entrepreneurial turnover (EP3), but only after the new entrepreneur has had enough time to move the startup along the development stage (EP4). To probe this we estimate the following regression:

$$
\log _{-} F S_{i}=\alpha+\beta_{1} E T_{i}+\beta_{2} \text { tenure }_{i}+\beta_{3} E T_{-} \text {tenure }_{i}+\beta_{3} S T_{i}+\gamma X_{i}+\varepsilon_{i},
$$

where $F S_{i}$ is the firm size at the time of survey, measured by paid capital or by the number of employees, while all other variables are the same as in regression (14) above. As the amount of raised capital and possibly also the number of employees will be strongly influenced by the whole firm history, including the timing of entry, we once again control for firm age non-parametrically in regression (15) by including 48 startup founding year dummies. The theoretical prediction is that the coefficient $\beta_{3}$ in regression (12) should be positive and significant.

The estimation results in Table 5 show a pattern that is consistent with theory, regardless of whether paid capital or the number of employees are used as a measure of firm size. In both cases, the coefficient on the non-founder CEO by itself is statistically not significant at conventional levels (it is actually indistinguishable from zero when log paid capital is the dependent variable and is negative 0.3 but with comparable standard errors when log number of employees is the dependent variable). The prediction that $\beta_{3}$ should be positive and significant holds in both regressions. In fact, even the magnitude 
of this coefficient is the same, although it is statistically significant only at 10 percent level in the regression with log paid capital as the dependent variable (at 5 percent level with log number of employees as the dependent variable). The estimated magnitude implies that one extra year of tenure of a new CEO increases paid capital and the number of employees by about 11 percent. Since the median tenure of a non-founder CEO in the sample is 3 years, while the mean is 4.47 years, we estimate that entrepreneurial turnover increases the firm size (measured either by capital or by the number of employees) by 33 percent at the median and by almost 45 percent at the mean.

Not surprisingly, initial size and patenting activity in the US are strong independent predictors of larger size at survey time (the latter especially so with regard to raised capital). Among other controls (not shown), founding year dummies and main activity area dummies are jointly highly statistically significant, but startup background variables are jointly statistically insignificant. CEO background characteristics, on the other hand, are jointly statistically significant at 5 percent level in both regressions.

Finally in Table 6 we look at the stages of the IPO process as a measure of a startup's success in bringing high value for its shareholders. The respondents to the 2008 survey were asked to answer the question about their IPO event or intention. The four possible answers were (i) "has already conducted IPO", (ii) "intend to conduct at IPO at a specific date and market" (specifying the date and the market), (iii) "consider IPO but no specific plans at the moment", and (iv) "have no IPO plans". Before presenting the 
regression results, the top part of Table 6 shows the summary statistics. Firms managed by non-founders are more likely to have already conducted IPO or to have specific plans to conduct IPO than firms managed by founders, and they are also less likely to have no intention of conducting IPO at all. The statistical power of the mean comparison $t$-test is limited because of limited number of observations, but with regard to having no intention of IPO the one-sided test is statistically significant at 5 percent level and the two-sided test is significant at 10 percent level (in the two other cases only the one-sided test is statistically significant at 10 percent level).

The bottom part of Table 6 presents the results of estimating an ordered probit regression where the four answers above are classified as four different stages of IPO process, with (i) being the highest and (iv) the lowest stage. Both with and without extra controls for changes in core technology, patenting activity in the US, log initial capital and venture capital financing, the non-founder entrepreneur dummy is positively and statistically significantly (at 5 percent level) associated with the startup being further along its way to conducting an IPO. Areas of activity are jointly statistically significant at 1 percent level, but founding year dummies are jointly statistically insignificant. Among other controls, US patenting activity dummy and venture capital financing are predictably strongly positively associated with IPO, but including these controls does not affect the coefficient on entrepreneurial turnover (if anything, it makes it even somewhat larger). 


\section{Conclusions and discussion}

We have presented a model where science-based businesses started by academic researchers with relatively low entrepreneurial ability may be taken to the commercialization stage by high-ability entrepreneurs who do not have a project (seed) of their own. An equilibrium exists where such entrepreneurial turnover coexists with startups that are continuously managed by their academic founders. The theory predicts that the startups that experience entrepreneurial turnover will tend to outperform the startups that are managed by their founders in terms of $R \& D$ expenditure, firm size and ultimate success rates (such as IPO events), with capital raised but not R\&D expenditure also influenced by how long the new entrepreneur had been in charge.

Startups that are developed by high-ability entrepreneurs invest to learn the quality of their seed and discard useless seeds. This insight is somewhat similar to the “cash-out or flame-out" idea explored by Arora and Nandkumar [2009]. But in our model it is not just entrepreneurs with the highest opportunity cost who choose the investment option, but entrepreneurs with the lowest opportunity cost also do the same, in anticipation of hiring high-ability entrepreneurs to develop their seed if it turns out to be good.

The basic framework of the model is closely related to the ideas first explored in Jovanovic and Braguinsky [2004]. In that paper we assumed, however, that projects were traded in the market, and not entrepreneurial talent. It should be emphasized that all what really matters is the idea that good seeds are matched with high-ability entrepreneurs, and 
this can equally happen through seeds changing hands if the market for seeds were to replace the market for entrepreneurs in our model, without changing the nature of the equilibrium in Section 3. Our decision to adopt the market for entrepreneurs rather than the market for seeds for the purposes of this paper was driven partly by theory and partly by empirical considerations. From a theoretical perspective, we agree with the concept (e.g., in Zingales [2000]) that while projects may indeed more easily change hands than management teams in traditional types of business, in science-based business the tacit knowledge of the founder might be essential also at the development stage, making it difficult to move the seed. And on the empirical side, our data indicate that even though entrepreneurial turnover is quite common, the controlling stake in the firm for most part is retained by the founder despite the change in the CEO (Honjo et al. [2009]).

When tested against the data on a representative sample of biotechnology startups in Japan, the main predictions of the theory are strongly supported. Both theory and empirical findings supporting it indicate that at the stage of commercialization, science-based businesses may after all be subject to many of the same kind of regularities as non science-based businesses, so that the emergence of biotechnology and other science-based industries in the past couple of decades does not necessarily require drastically changing the established theory of the firm.

Our study leads to important policy and managerial implications. In terms of policy, establishing a smoothly functioning market for entrepreneurial talent, including 
lowering the costs of investing into learning the commercial potential of a basic research seed and reducing incentives for academic researchers to hold on to their seeds for too long, may be at least as important as supporting the basic research to produce such seeds in the first place. Our findings also imply that science-based businesses should be proactively seeking experienced managers if they want to evaluate and develop their seeds with a view

to generating high returns. Zingales [2000] was right when he conjectured that firms organized around high-level human capital might well be unstable and dysfunctional. In contrast to his view, however, our theory and evidence show that such an outcome is not inevitable.

The nature of science-based business and its implications for the theory of the firm and industrial organization have been the subject of a hot debate in the literature. Our paper does not aim to resolve this debate once and for all. But it suggests that "traditional" theories of markets and firm can be fruitfully applied to understanding and analyzing science-based businesses just as they have been applied to more conventional types of businesses and industries.

\section{References}

Aghion, Phillippe, Mathias Dewatripont, and Jeremy C. Stein, 2008. “Academic Freedom, Private-Sector Focus, and the Process of Innovation,” Rand Journal of Economics, 39 (3), 617-635.

Arora Ashish and Anand Nandkumar, 2009. "Cash-out or Flame-out! Opportunity Cost and 
Entrepreneurial Strategy: Theory and Evidence from the Information Security Industry," NBER Working Paper 15532, Cambridge, Massachusetts.

Baum, Joel A.C., Tony Calabres, and Brian S. Silverman, 2000. "Don't Go It Alone: Alliance Network Composition and Startups' Performance in Canadian Biotechnology,” Strategic Management Journal, 21 (3), 267-294.

Bhidé, Amar V., 2000. The Origin and Evolution of New Business, Oxford University Press: Oxford, England.

Braguinsky, Serguey, Steven Klepper and Atsushi Ohyama, 2010. "High-Tech Entrepreneurship,” Working Paper, Carnegie Mellon University.

Gans, Joshua S., David H. Hsu, and Scott Stern, 2002. "When Does Start-up Innovation Spur the Gale of Creative Destruction," Rand Journal of Economics, 33 (4), 571-586.

Gittelman, Michelle and Bruce Kogut, 2003. "Does Good Science Lead to Valuable Knowledge? Biotechnology Firms and the Evolutionary Logic of Citation Patterns,” Management Science, 49 (4), 366-382.

Honjo, Yuji, Sadao Nagaoka, Kenta Nakamura, Setsuo Morishita, and Yumi Shimizu, 2009. "Biobencha-no sannyu-to seicho (Entry and Growth of Bioventures)", Working paper, Hitotsubashi University, Institute of Innovation Research (in Japanese).

Jensen, Richard and Marie Thursby, 2001. "Proofs and Prototypes for Sale: The Licensing of University Inventions,” American Economic Review, 91 (1), 240-259.

Jovanovic, Boyan and Serguey Braguinsky, 2004. "Bidder's Discounts and Target Premia 
in Takeovers," American Economic Review, 94 (1), 46-56.

Kaplan, Steven N., Berk A. Sensoy, and Per Strömberg, 2009. "Should Investors Bet on the Jockey or the Horse? Evidence from the Evolution of Firms from Early Business Plans to Public Companies," The Journal of Finance, 64 (1), 75-115.

Klepper, Steven, 2002. "The Capabilities of New Firms and the Evolution of the US Automobile Industry," Industrial and Corporate Change, 11 (4), 645-666.

Lerner, Josh, and Robert Merges, 1998. "The Control of Technology Alliances: An Empirical Analysis of the Biotechnology Industry," The Journal of Industrial Economics, 46 (2), 125-156.

Motohashi, Kazuyuki, 2007. “Comparing Biotechnology Startups' Activities Between Japan and US," available on-line at http://www.mo.t.u-tokyo.ac.jp/

Pisano, Gary P., 2010. “The Evolution of Science-Based Business: Innovating How We Innovate," Industrial and Corporate Change, 19 (2), 465-482.

Rajan, Raghuram G., and Luigi Zingales, 2001. "The Firm as a Dedicated Hierarchy: A Theory of the Origins and Growth of Firms," Quarterly Journal of Economics, 116 (3), 805-851.

Rothaermel, Frank T. and David L. Deeds, 2004. "Exploration and Exploitation Alliances in Biotechnology: A System of New Product Development," Strategic Management Journal, 25 (3), 201-221.

Shan, Weijan, Gordon Walker and Bruce Kogut, 1994. "Interfirm Cooperation and Startup 
Innovation in the Biotechnology Industry," Strategic Management Journal, 15 (4), 387-394.

Shane, Scott, 2002. "Selling University Technology: Patterns from MIT," Management Science, 48 (1), 122-137.

Thursby, Jerry G., and Marie C. Thursby, 2002. "Who Is Selling the Ivory Tower? Sources of Growth in University Licensing," Management Science, 48 (1), 90-104.

Zingales, Luigi, 2000. "In Search of New Foundations," Journal of Finance, 55 (4), $1623-1653$.

Zucker, Lynne G., and Michael R. Darby, 2006. "Movement of Start Scientists and Engineers and High-Tech Firm Entry," NBER Working Paper, No. 12712, Cambridge, Massachusetts.

Zucker, Lynne G., Michael R. Darby, and Marilynn B. Brewer, 1998. "Intellectual Human Capital and the Birth of U.S. Biotechnology Enterprises," American Economic Review, 88 (1), 290-306. 
Figure 1. Equilibrium behavior by startup type

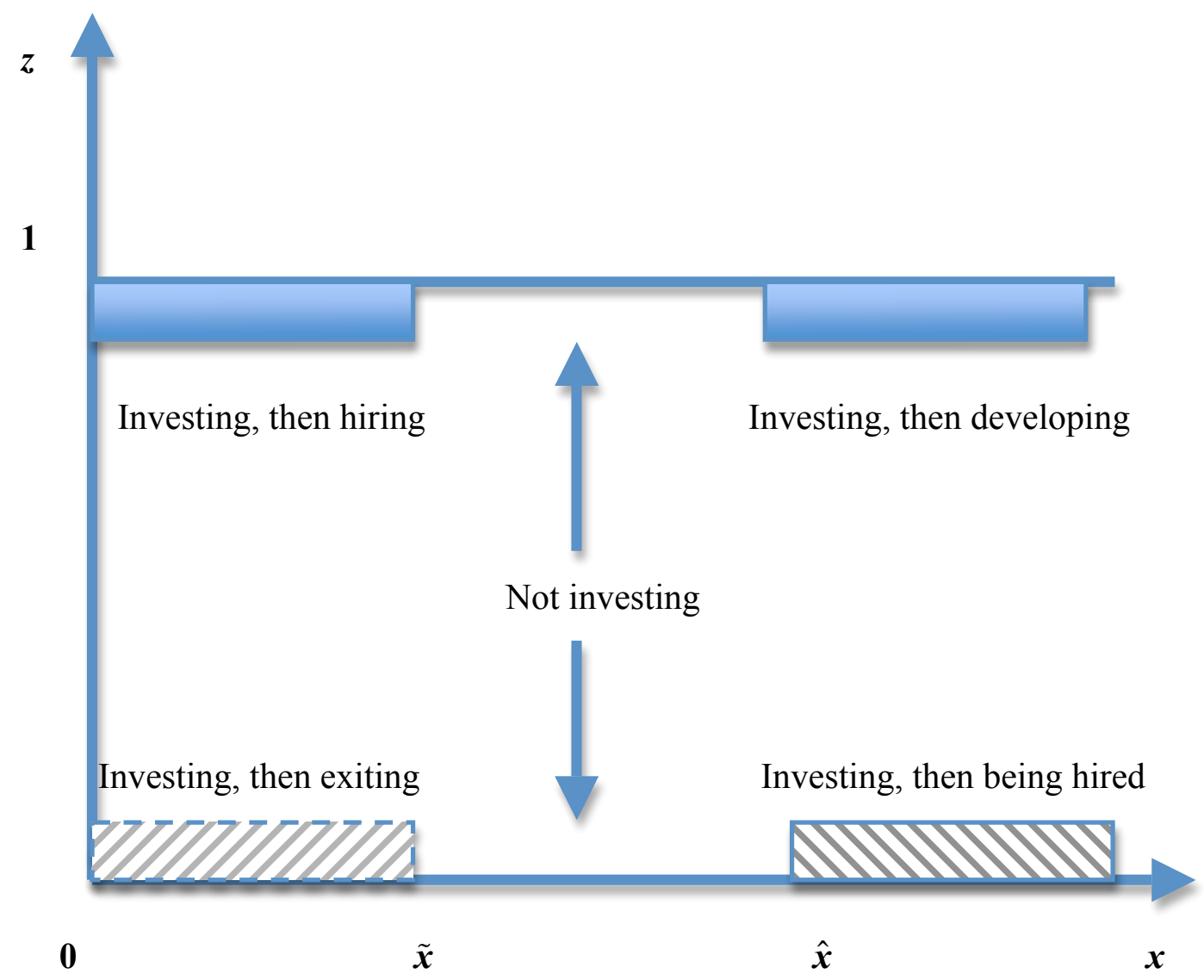


Figure 2. An example of equilibrium, case (i) in Proposition 2.

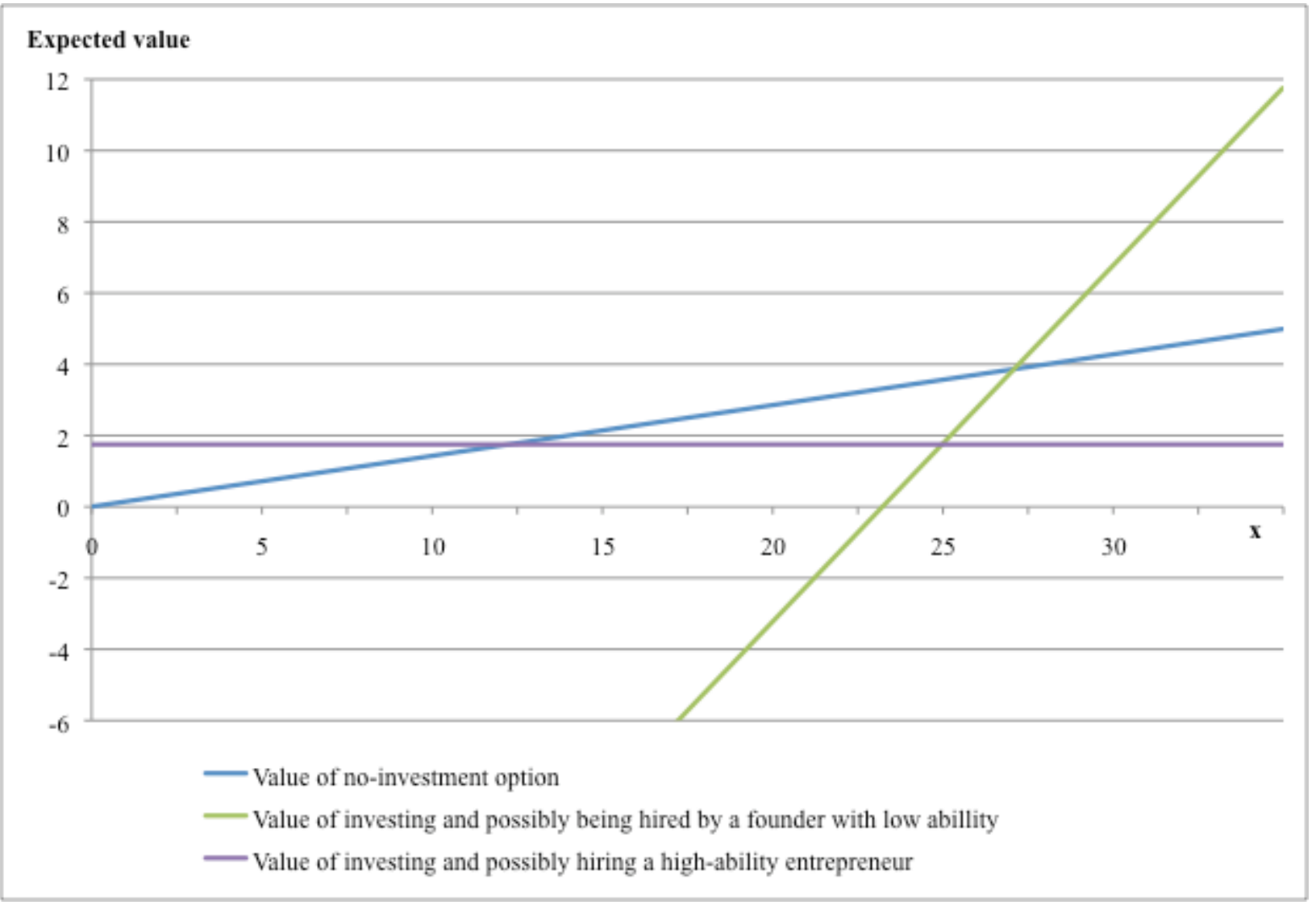

Parameter values: $\lambda=0.15, C=2, \beta=0.95, x_{\max }=40, q=25$. 
Figure 3. An example of equilibrium, case (ii) in Proposition 2.

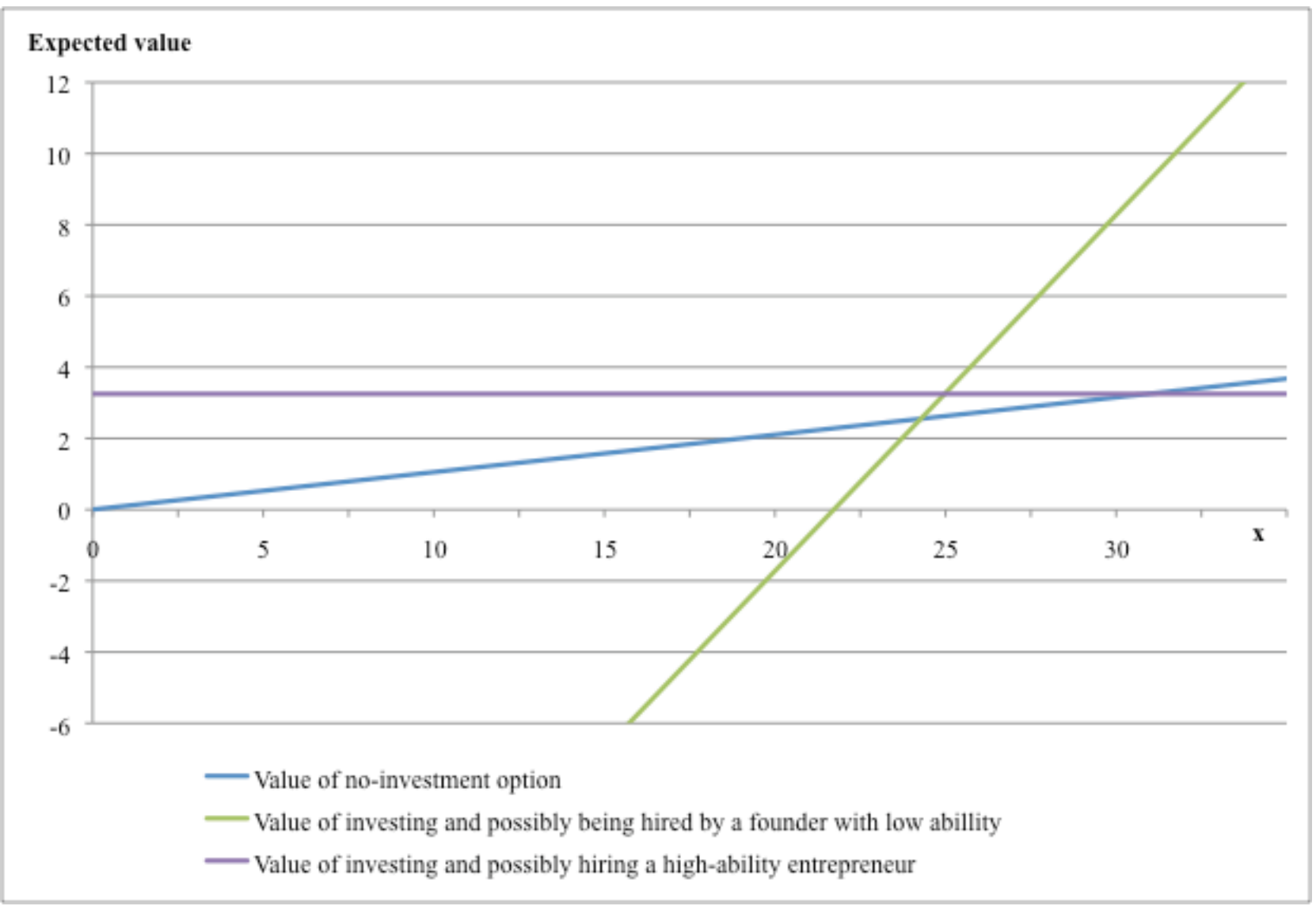

Parameter values: $\lambda=0.15, C=0.5, \beta=0.7, x_{\max }=40, q=25$. 
Table 1. Some summary statistics

\begin{tabular}{|c|c|c|}
\hline \multicolumn{3}{|l|}{ Fraction founded: } \\
\hline \multicolumn{2}{|l|}{ Before 1990} & 7.54 \\
\hline \multicolumn{2}{|l|}{ 1990-1999 } & 20.70 \\
\hline \multicolumn{2}{|l|}{$2000-2007$} & 71.75 \\
\hline \multicolumn{3}{|l|}{ Fraction with: } \\
\hline \multicolumn{2}{|l|}{ Startup technology from basic research } & 52.94 \\
\hline \multicolumn{2}{|l|}{ Seed turnover } & 27.98 \\
\hline \multicolumn{2}{|l|}{ Entrepreneurial turnover } & 37.07 \\
\hline \multirow[b]{2}{*}{ Firm age (years) } & Mean & 10.35 \\
\hline & Standard Deviation & 9.19 \\
\hline \multirow[b]{2}{*}{ Years since CEO change (if any) } & Mean & 4.33 \\
\hline & Standard Deviation & 3.92 \\
\hline \multirow[b]{2}{*}{ R\&D expenditure (mln. yen) } & Mean & $1,911.3$ \\
\hline & Standard Deviation & $7,336.7$ \\
\hline \multirow[b]{2}{*}{ Amount of capital raised (mln. yen) } & Mean & $3,580.8$ \\
\hline & Standard Deviation & $9,872.7$ \\
\hline \multirow[b]{2}{*}{ Number of employees } & Mean & 18.0 \\
\hline & Standard Deviation & 26.6 \\
\hline
\end{tabular}


Table 2. Testing EP1

\begin{tabular}{|c|c|c|c|c|}
\hline Cohorts of entry & Before 1990 & $1990-1999$ & $2000-2004$ & $2005-2009$ \\
\hline Number of startups & 43 & 118 & 276 & 133 \\
\hline Fraction in total & 7.54 & 20.70 & 48.42 & 23.33 \\
\hline \multicolumn{5}{|c|}{ - Startups with founder CEOs at the time of survey } \\
\hline $\begin{array}{l}\text { Fraction with startup } \\
\text { technology from basic research }\end{array}$ & 23.08 & 32.08 & 51.22 & 73.20 \\
\hline \multicolumn{5}{|l|}{ Fraction with CEOs } \\
\hline Former scientists & 26.67 & 47.37 & 51.47 & 57.55 \\
\hline \multicolumn{5}{|l|}{ Formerly employed in: } \\
\hline Academia & 6.25 & 12.28 & 21.13 & 37.38 \\
\hline Large corporations & 18.75 & 54.39 & 38.73 & 30.84 \\
\hline Other non-academia & 75.00 & 33.33 & 40.14 & 31.78 \\
\hline \multicolumn{5}{|c|}{ - Startups with non-founder CEOs at the time of survey } \\
\hline $\begin{array}{c}\text { Fraction with startup } \\
\text { technology from basic research }\end{array}$ & 26.32 & 37.78 & 61.96 & 62.50 \\
\hline \multicolumn{5}{|l|}{ Fraction with CEOs } \\
\hline Former scientists & 52.63 & 47.83 & 35.85 & 25.00 \\
\hline \multicolumn{5}{|l|}{ Formerly employed in: } \\
\hline Academia & 0.00 & 24.44 & 17.31 & 5.88 \\
\hline Large corporations & 45.00 & 48.89 & 49.04 & 58.82 \\
\hline Other non-academia & 55.00 & 26.67 & 33.65 & 35.29 \\
\hline
\end{tabular}

Note: Academia includes universities and public research corporations. 
Table 3. Estimations of regression (13)

\begin{tabular}{|c|c|c|c|c|c|c|c|c|c|}
\hline \multicolumn{2}{|c|}{ Dependent variable } & \multicolumn{4}{|c|}{$\begin{array}{l}\text { Log paid capital } \\
\text { in founding year }\end{array}$} & \multicolumn{4}{|c|}{$\begin{array}{c}\text { Log number of employees in } \\
\text { founding year }\end{array}$} \\
\hline \multirow{2}{*}{$\begin{array}{l}\text { Non-founder } \\
\text { CEO }\end{array}$} & Coefficient & 0.719 & $* * *$ & 0.629 & $* * *$ & 0.381 & $* * *$ & 0.405 & $* * *$ \\
\hline & St. Error & 0.331 & & 0.177 & & 0.118 & & 0.125 & \\
\hline \multirow{2}{*}{$\begin{array}{l}\text { Basic research } \\
\text { core technology }\end{array}$} & Coefficient & & & -0.678 & $* * *$ & & & -0.191 & \\
\hline & St. Error & & & 0.186 & & & & 0.123 & \\
\hline \multirow{2}{*}{$\begin{array}{l}\text { Diversifying } \\
\text { entrant }\end{array}$} & Coefficient & & & -0.637 & $*$ & & & 0.410 & $*$ \\
\hline & St. Error & & & 0.355 & & & & 0.213 & \\
\hline \multirow{2}{*}{$\begin{array}{l}\text { US patent } \\
\text { activity dummy }\end{array}$} & Coefficient & & & 0.582 & $* * *$ & & & 0.207 & $*$ \\
\hline & St. Error & & & 0.218 & & & & 0.118 & \\
\hline \multirow[b]{2}{*}{ Constant } & Coefficient & 0.992 & & 0.430 & & 0.875 & $* * *$ & 0.826 & $* * *$ \\
\hline & St. Error & 0.626 & & 0.648 & & 0.137 & & 0.236 & \\
\hline \multicolumn{2}{|l|}{ Other controls } & \multicolumn{2}{|c|}{$\begin{array}{l}\text { Founding year } \\
\text { dummies, } \\
\text { R\&D activity } \\
\text { area dummies }\end{array}$} & \multicolumn{2}{|c|}{$\begin{array}{l}\text { All other } \\
\text { controls too }\end{array}$} & \multicolumn{2}{|c|}{$\begin{array}{l}\text { Founding year } \\
\text { dummies, } \\
\text { R\&D activity } \\
\text { area dummies }\end{array}$} & \multicolumn{2}{|c|}{$\begin{array}{l}\text { All other } \\
\text { controls too }\end{array}$} \\
\hline \multicolumn{2}{|c|}{ Number of observations } & \multicolumn{2}{|l|}{403} & \multicolumn{2}{|c|}{366} & \multicolumn{2}{|c|}{379} & \multicolumn{2}{|c|}{347} \\
\hline \multicolumn{2}{|l|}{ Number of firms } & \multicolumn{2}{|l|}{275} & \multicolumn{2}{|c|}{262} & \multicolumn{2}{|c|}{260} & \multicolumn{2}{|c|}{248} \\
\hline \multicolumn{2}{|c|}{ Adjusted R-squared } & \multicolumn{2}{|c|}{0.094} & \multicolumn{2}{|c|}{0.186} & \multicolumn{2}{|c|}{0.110} & \multicolumn{2}{|c|}{0.147} \\
\hline
\end{tabular}

Note: $* * *$ indicates that the coefficient is significant at 1 percent level, ${ }^{* *}$ at 5 percent level, and * at 10 percent level. Robust clustered standard errors. Other controls (not shown) in columns 2 and 4 include CEO prior job and prior occupation dummies, CEO's education dummies, seven area of activity dummies and 48 founding year dummies. 
Table 4. Estimations of regression (14)

\begin{tabular}{|c|c|c|c|c|c|c|c|c|c|}
\hline \multicolumn{2}{|l|}{ Dependent variable } & \multicolumn{8}{|c|}{ Log $R \& D$ expenditure in survey year } \\
\hline \multirow[b]{2}{*}{ Non-founder CEO } & Coefficient & 0.714 & $*$ & 0.750 & $* * *$ & 0.731 & $* * *$ & 0.475 & $* *$ \\
\hline & St. Error & 0.375 & & 0.217 & & 0.242 & & 0.212 & \\
\hline \multirow[b]{2}{*}{ CEO tenure } & Coefficient & -0.006 & & \multirow{2}{*}{\multicolumn{2}{|c|}{ Excluded }} & \multirow{2}{*}{\multicolumn{2}{|c|}{ Excluded }} & \multirow{2}{*}{\multicolumn{2}{|c|}{ Excluded }} \\
\hline & St. Error & 0.032 & & & & & & & \\
\hline \multirow{2}{*}{$\begin{array}{l}\text { Non-founder CEO } \\
\text { inter. w/tenure }\end{array}$} & Coefficient & 0.000 & & \multirow{2}{*}{\multicolumn{2}{|c|}{ Excluded }} & \multirow{2}{*}{\multicolumn{2}{|c|}{ Excluded }} & \multirow{2}{*}{\multicolumn{2}{|c|}{ Excluded }} \\
\hline & St. Error & 0.047 & & & & & & & \\
\hline \multirow[b]{2}{*}{ Firm age } & Coefficient & 0.102 & $* *$ & 0.095 & $* * *$ & 0.058 & $*$ & 0.004 & \\
\hline & St. Error & 0.043 & & 0.027 & & 0.031 & & 0.029 & \\
\hline \multirow[b]{2}{*}{ Firm age squared } & Coefficient & -0.002 & $* *$ & -0.002 & $* * *$ & -0.001 & * & -0.001 & \\
\hline & St. Error & 0.001 & & 0.001 & & 0.001 & & 0.000 & \\
\hline \multirow{2}{*}{$\begin{array}{l}\text { US patent activity } \\
\text { dummy }\end{array}$} & Coefficient & & & & & 1.021 & $* * *$ & 0.848 & $* * *$ \\
\hline & St. Error & & & & & 0.236 & & 0.229 & \\
\hline \multirow{2}{*}{$\begin{array}{l}\text { Log number of } \\
\text { employees }\end{array}$} & Coefficient & & & & & & & 0.734 & $* * *$ \\
\hline & St. Error & & & & & & & 0.104 & \\
\hline \multirow[b]{2}{*}{ Constant } & Coefficient & 1.861 & $* * *$ & 1.858 & $* * *$ & 2.010 & $* * *$ & 0.874 & $*$ \\
\hline & St. Error & 0.278 & & 0.267 & & 0.457 & & 0.470 & \\
\hline \multicolumn{2}{|l|}{ Other controls } & \multicolumn{2}{|c|}{$\begin{array}{c}\text { Activity area } \\
\text { dummies }\end{array}$} & \multicolumn{2}{|c|}{$\begin{array}{c}\text { Activity area } \\
\text { dummies }\end{array}$} & \multicolumn{2}{|c|}{$\begin{array}{l}\text { All other } \\
\text { controls too }\end{array}$} & \multicolumn{2}{|c|}{$\begin{array}{c}\text { All other } \\
\text { controls too }\end{array}$} \\
\hline \multicolumn{2}{|c|}{ Number of observations } & \multicolumn{2}{|c|}{298} & \multicolumn{2}{|c|}{298} & \multicolumn{2}{|c|}{276} & \multicolumn{2}{|c|}{273} \\
\hline \multicolumn{2}{|l|}{ Number of firms } & \multicolumn{2}{|c|}{211} & \multicolumn{2}{|c|}{211} & \multicolumn{2}{|c|}{201} & \multicolumn{2}{|c|}{198} \\
\hline \multicolumn{2}{|l|}{ Adjusted R-squared } & \multicolumn{2}{|c|}{0.269} & \multicolumn{2}{|c|}{0.274} & 0.35 & & 0.47 & \\
\hline
\end{tabular}

Notes: ${ }^{* * *}$ indicates that the coefficient is significant at 1 percent level, $* *$ at 5 percent level, and $*$ at 10 percent level. Robust clustered standard errors. Other controls (not shown) in columns 2 and 4 include CEO prior job and prior occupation dummies, CEO's education dummies, dummy equal to 1 if entrant from a related industry and zero otherwise, and dummy equal to 1 if the startup technology came from basic research and zero otherwise. 
Table 5. Estimations of regression (15)

\begin{tabular}{|c|c|c|c|c|c|}
\hline \multicolumn{2}{|l|}{ Dependent variable } & \multicolumn{2}{|c|}{$\begin{array}{l}\text { Log paid capital in } \\
\text { survey year }\end{array}$} & \multicolumn{2}{|c|}{$\begin{array}{c}\text { Log \# of employees in } \\
\text { survey year }\end{array}$} \\
\hline \multirow[b]{2}{*}{ Non-founder CEO } & Coefficient & -0.005 & & -0.297 & \\
\hline & St. Error & 0.422 & & 0.268 & \\
\hline \multirow[b]{2}{*}{ CEO tenure } & Coefficient & 0.042 & & -0.022 & \\
\hline & St. Error & 0.047 & & 0.023 & \\
\hline \multirow{2}{*}{$\begin{array}{l}\text { Non-founder CEO inter. } \\
\text { w/tenure }\end{array}$} & Coefficient & 0.108 & $*$ & 0.108 & $* *$ \\
\hline & St. Error & 0.063 & & 0.043 & \\
\hline \multirow{2}{*}{$\begin{array}{l}\text { Change in core technology } \\
\text { since founding }\end{array}$} & Coefficient & -0.057 & & 0.063 & \\
\hline & St. Error & 0.195 & & 0.137 & \\
\hline \multirow[b]{2}{*}{ US patent dummy } & Coefficient & 0.762 & $* * *$ & 0.217 & $*$ \\
\hline & St. Error & 0.207 & & 0.113 & \\
\hline \multirow{2}{*}{$\begin{array}{l}\text { Log initial paid capital (\# } \\
\text { of employees) }\end{array}$} & Coefficient & 0.287 & $* * *$ & 0.307 & $* * *$ \\
\hline & St. Error & 0.102 & & 0.105 & \\
\hline \multirow[b]{2}{*}{ Constant } & Coefficient & 0.941 & & 0.972 & $* * *$ \\
\hline & St. Error & 0.712 & & 0.308 & \\
\hline \multicolumn{2}{|l|}{ Other controls } & \multicolumn{4}{|c|}{$\begin{array}{l}\text { Activity areas, CEO and startup background } \\
\text { dummies, } 48 \text { founding year dummies }\end{array}$} \\
\hline \multicolumn{2}{|l|}{ Number of observations } & \multicolumn{2}{|l|}{361} & \multicolumn{2}{|c|}{339} \\
\hline \multicolumn{2}{|l|}{ Number of firms } & \multicolumn{2}{|l|}{259} & \multicolumn{2}{|c|}{243} \\
\hline \multicolumn{2}{|l|}{ Adjusted R-squared } & \multicolumn{2}{|c|}{0.426} & \multicolumn{2}{|c|}{0.373} \\
\hline
\end{tabular}

Notes: $* * *$ indicates that the coefficient is significant at 1 percent level, $* *$ at 5 percent level, and $*$ at 10 percent level. Robust clustered standard errors. Other controls (not shown) include 48 founding year dummies, seven areas of main activity dummies, CEO prior job and prior occupation dummies, CEO's education dummies, dummy equal to 1 if entrant from a related industry and zero otherwise, and dummy equal to 1 if the startup technology came from basic research and zero otherwise. 
Table 6. Effect on stages of IPO

\begin{tabular}{|c|c|c|c|c|c|}
\hline \multicolumn{2}{|c|}{ Firms managed by: } & Non-founder & Founder & \multicolumn{2}{|c|}{ t-test (mean comparison) } \\
\hline \multicolumn{2}{|l|}{ Stages of IPO: } & \multicolumn{2}{|l|}{ Fractions } & One-sided & Two-sided \\
\hline \multicolumn{2}{|l|}{ Have conducted IPO } & 0.064 & 0.024 & 0.081 & 0.162 \\
\hline \multicolumn{2}{|l|}{ Have specific IPO plan } & 0.096 & 0.049 & 0.090 & 0.180 \\
\hline \multicolumn{2}{|l|}{ No IPO intention } & 0.383 & 0.500 & 0.966 & 0.068 \\
\hline \multicolumn{2}{|l|}{ Number of observations } & 94 & 164 & & \\
\hline \multicolumn{2}{|l|}{ Dependent variable } & \multicolumn{4}{|c|}{ IPO stage (ordered probit) } \\
\hline \multirow[b]{2}{*}{ Non-founder CEO } & Coefficient & 0.420 & $* *$ & 0.488 & $* *$ \\
\hline & St. Error & 0.192 & & 0.222 & \\
\hline \multirow{2}{*}{$\begin{array}{l}\text { Core technology } \\
\text { changed since founded }\end{array}$} & Coefficient & & & -0.299 & \\
\hline & St. Error & & & 0.218 & \\
\hline \multirow{2}{*}{$\begin{array}{l}\text { US patenting activity } \\
\text { dummy }\end{array}$} & Coefficient & & & 0.523 & $* *$ \\
\hline & St. Error & & & 0.216 & \\
\hline \multirow[b]{2}{*}{ Log initial paid capital } & Coefficient & & & -0.027 & \\
\hline & St. Error & & & 0.078 & \\
\hline \multirow[b]{2}{*}{$\mathrm{VC}$ financing dummy } & Coefficient & & & 1.097 & $* * *$ \\
\hline & St. Error & & & 0.219 & \\
\hline Other controls & \multicolumn{5}{|c|}{ Area of activity and 48 founding year dummies } \\
\hline \multicolumn{2}{|c|}{ Number of observations (firms) } & 221 & & 200 & \\
\hline \multicolumn{2}{|l|}{ Pseudo R-squared } & 0.168 & & 0.269 & \\
\hline
\end{tabular}

Notes: P-values in mean comparison t-test with unequal variance. ${ }^{* *}$ indicates that the coefficient is significant at 5 percent level. "IPO stage" refers to four answer categories as described in the main text. 


\section{Appendix}

\section{Proof of Proposition 2.}

The proof proceeds by construction. To begin with, notice that for $q$ close to 0 the left-hand side of (11) tends to zero, while the right-hand side tends to $(1-\lambda)[1-F(C / \lambda(1-\beta \lambda))]>0$, since $x_{\max }>C /(1-\beta \lambda)$ by assumption. Also the left-hand side of (11) is strictly increasing in $q$, while the right-hand side is decreasing in $q$. There are two possible cases.

--- Case (i). There is some $\hat{q}<C / \lambda(1-\beta)$ such that (11) is satisfied with equality at $q=\hat{q}$. Conditions (10) and (11) yield, after some manipulations, that $\hat{x}>\tilde{x}$ at such a $\hat{q}$. Then (9) says that the number of entrepreneurs from the top region moving to work with seeds owned by the startups with $z=1$ in the bottom region is $\lambda F(\tilde{x})=(1-\lambda)[1-F(\hat{x})]$. Together with (10) this implies that (11) is indeed the desired equilibrium.

--- Case (ii). Assume now that at $q=C / \lambda(1-\beta)$ there is still excess supply of seedless entrepreneurs (the left-hand side of (11) is smaller than the right-hand side). This means that $q$ has to increase further. But if $q>C / \lambda(1-\beta)$, the no-investment option becomes less attractive than paying $C$ and letting another entrepreneur develop the seed if $z=1$ for founder $\tilde{x}$, so that only the bottom region $x \in[0, \hat{x})$ and the top region $x \in\left[\hat{x}, x_{\max }\right]$ remain as part of an equilibrium (notice that $\hat{x} \leq \tilde{x}$ if and only if $q \geq C / \lambda(1-\beta))$. The number of entrepreneurs from the top region moving to work with seeds owned by the startups with $z=1$ in the bottom region is $\lambda F(\hat{x})=(1-\lambda)[1-F(\hat{x})]$, while founder $\hat{x}$ is indifferent between paying $C$ and receiving $q$ with probability $\lambda$, on the one hand, and choosing the investment option with the expected private value $E_{I}$ as in (2), on the other hand. Hence, we must have $\lambda q-C=\hat{x}-C-(1-\lambda) q \Rightarrow \hat{x}=q$, so that if equilibrium exists, (12) must be satisfied.

But since the left-hand side in (12) tends to 1 as $q$ becomes high, while the right-hand side tends to zero (because $x_{\max }$ is finite), an equilibrium will always exist.

\section{Proof of Proposition 3.}

To be completed. 